\title{
Sistem Informasi Akuntansi Penjualan Dan Persediaan Barang Pada Toko Dua Putri Pekanbaru
}

\author{
${ }^{1}$ Widiyanti, ${ }^{2}$ Adhi Wibowo \\ ${ }^{1}$ STMIK Dharmapala Riau, ${ }^{2}$ STIKOM Yos Sudarso
}

\author{
Alamat Surat \\ Email: widiyanti@lecturer.stmikdharmapalariau.ac.id
}

Article History:

Diajukan: 30-03-2021; Direvisi: 14-04-2021; Diterima: 28-04-2021

\begin{abstract}
ABSTRAK
Penjualan merupakan pendapatan yang berasal dari penjualan produk perusahaan, disajikan setelah dikurangi potongan penjualan dan retur penjualan. Persediaan adalah istilah yang diberikan untuk aktiva yang akan dijual dalam kegiatan normal atau aktiva yang dimasukkan secara langsung atau tidak langsung ke dalam barang yang akan di produksi dan kemudian dijual.. Penelitian ini menggunakan sumber data primer dan sekunder, metode pengumpulan data dengan cara penelitian lapangan (Field Reseach) dan studi literatur (Library Research). Objek penelitian ini adalah Toko Dua Putri Pekanbaru yang merupakan suatu usaha dagang yang menjual bermacam-macam kebutuhan sehari-hari, seperti beras, gula, minyak, tepung berbagai merek mie instan, berbagai merek rokok, makanan ringan, dan berbagai jenis minuman mulai dari minuman dalam kemasan gelas, botol beling, dan botol plastik dan lain-lain.

Toko Dua Putri Pekanbaru dalam mengelolah data pencatatan penjualan dan persediaan barang masih menggunakan cara manual manual yaitu melakukan catatan tulis tangan di kertas biasa dan menggunakan alat kalkulator dalam penjumlahan barang. Sehingga membutuhkan tenaga dan dan waktu yang cukup lama dalam proses pencatatan penjualan dan persediaan barang. Berdasarkan sistem informasi akuntansi penjualan dan pencatatan persediaan yang sedang berjalan dalam toko, maka diusulkan sistem akuntansi yang terkomputerisasi dengan menggunakan sebuah aplikasi yaitu Microsoft Excel
\end{abstract}

Kata Kunci: Akuntansi; penjualan; persediaan

\section{ABSTRACT}

Sales represent revenue originating from the sale of the company's products, which is presented after deducting sales discounts and sales returns. Inventory is the term given to assets to be sold in normal activities or assets that are included directly or indirectly into goods to be produced and then sold. This research uses primary and secondary data sources, data collection methods are by means of field research. (Field Research) and literature studies (Library Research). The object of this research is Toko Dua Putri Pekanbaru, which is a trading business that sells a variety of daily necessities, such as rice, sugar, oil, flour, various brands of instant noodles, various brands of cigarettes, snacks, and various types of beverages ranging from beverages. in glass packaging, glass bottles, and plastic bottles and others.

Toko Dua Putri Pekanbaru in managing sales and inventory recording data still uses manual manual methods, namely making handwritten notes on plain paper and using a calculator to add goods. So it requires a long time and energy in the process of recording sales and inventory of 
goods. Based on the sales accounting information system and inventory recording that is currently running in the store, a computerized accounting system is proposed using an application, namely Microsoft Excel.

Keywords: Accounting; sales; inventory

\section{PENDAHULUAN}

Perkembangan dunia usaha akan mengakibatkan besarnya persaingan yang harus dihadapi oleh setiap perusahaan maupun usahawan untuk mencapai tujuan yaitu memperoleh laba yang maksimal. Jika perusahaan tidak mampu bersaing menghadapi perusahaan lain yang terus berkembang, maka kelangsungan hidup dan kesempatan memperluas bidang usaha akan terancam.

Sistem informasi merupakan kombinasi dari manusia, fasilitas, alat, teknologi, media, prosedur dan pengendalian. Hal tersebut bermaksud menata jaringan komunikasi tertentu dan rutin yang bisa membantu manajemen, baik dalam keperluan intern maupun ekstern. Salah satu sistem informasi yang memegang peranan penting dalam organisasi perusahaan adalah sistem informasi akuntansi penjualan. Sistem informasi akuntansi penjualan menyangkut bagaimana organisasi perusahaan dapat merencanakan, mengkoordinasikan, menguasai atau mengontrol berbagai aktivitas penjualan yang dilaksanakan. Sistem informasi akuntansi penjualan juga berperan dalam penyediaan informasi untuk badan atau lembaga keuangan yang mempunyai kepentingan dalam menjalankan aktivitas-aktivitas perusahaan.

Dengan adanya suatu sistem informasi akuntansi penjualan yang memadai akan dapat menyajikan informasi akuntansi penjualan yang efektif yang diperlukan oleh pimpinan dan para manager untuk pengambilan keputusan. Disamping itu juga, sistem informasi akuntasi penjualan memiliki peranan dalam membantu pimpinan perusahaan dan para manager untuk memperoleh informasi yang bermanfaat khususnya dalam hal menentukan kebijakan penjualan yang akan ditempuh selanjutnya. Sistem informasi penjualan yang diterapkan harus dapat menciptakan suatu pengendalian intern penjualan yang baik atas adanya aktivitas yang dilakukan perusahaan. Adapun tujuan dari sistem informasi akuntansi penjualan ini adalah untuk membuat pengendalian yang kuat dalam situasi dimana tidak ada satu bagianpun yang mampu menyelesaikan transaksi tanpa melibatkan tanggungjawab orang lain.

Menurut Mulyadi (2010;3) dalam bukunya Sistem Informasi Akuntansi adalah organisasi formulir, catatan, dan laporan yang dikoordinasi sedemikian rupa untuk menyediakan informasi keuangan yang dibutuhkan oleh manajemen guna memudahkan pengelolaan perusahaan".

Salah satu usaha dagang yang membutuhkan sistem informasi akutansi adalah Toko Dua Putri Pekanbaru yang bergerak di bidang penjualan sembako dan grosir makanan yang menjual bermacam-macam kebutuhan sehari-hari, seperti beras, gula, minyak, tepung berbagai merek mie instan, berbagai merek rokok, makanan ringan, dan berbagai jenis minuman mulai dari minuman dalam kemasan gelas, botol beling, dan botol plastik dan lain-lain.

Berdasarkan hasil wawancara dengan pemilik Toko Dua Putri Pekanbaru yaitu Bapak Muhammad adanya permasalahan pada sistem akutansi penjualan dan persediaan masih melakukan pencatatan secara manual yang masih menggunakan buku besar secara tulis tangan sehingga sering terjadi kesalahan dalam pencatatan dan dalam memberikan informasi yang kurang akurat dan lambat. Dalam pencatatan persediaan di Toko Dua Putri Pekanbaru ini sering dijumpai masalah seperti hasil pencatatan persediaan barang tidak sesuai, kerusakan barang, pemasukan barang tidak sesuai dengan pemesanan barang kepada distibutor, dan lalai untuk mencatat pemesanan barang. Untuk itu diperlukan pengecekan barang setiap masuk dan keluar barang serta pemeriksaan catatan persediaan dengan hitungan yang sesuai. Karena cukup banyaknya produk barang yang masuk dan keluar sehingga perlu dilakukan pengendalian persediaan barang untuk mengatasi terjadinya permasalahan tersebut. 
Di dalam Toko Dua Putri Pekanbaru masih belum mempunyai sistem yang dapat memberikan informasi baik berupa data persediaan, data pemesanan maupun data penjualan. Ini dikarenakan kurangnya informasi dan penyimpanan pencatatan laporan stok barang tersebut sehingga toko kesulitan dalam mendapatkan informasi secara akurat. Seharusnya toko mempunyai sistem yang terintegrasi antara bagian tertentu dengan bagian yang bersangkutan supaya informasi yang didapat tidak salah. Contoh sistem pada bagian gudang harusnya terintegrasi dengan sistem pada bagian penjualan sehingga bagian penjualan tidak akan salah dalam pembuatan faktur penjualan dan tidak salah dalam memberikan informasi kepada pembeli apakah masih ada persediaan produk yang dijual atau tidak akan salah dalam pembuatan faktur. Dimana barang yang akan dibeli masih ada atau tidak, hal ini sangat perlu diperhatikan dalam persediaan barang pada toko.

Kegagalan sistem manual dalam penjualan disebabkan oleh sistem tersebut tidak dikembangkan sesuai dengan perkembangan usaha dagang yang dari hari ke hari bertambah pesat dan komplek. Sistem manual tidak lagi bekerja secara sempurna, maka diperlukan peranan komputer yang dapat melaksanakan pengolahan berbagai transaksi penjualan. Pencatatan transaksi penjualan yang dilakukan dengan bantuan perangkat lunak akan lebih cepat, teliti dan memudahkan apabila dibandingkan jika hal tersebut dilakukan secara manual. Oleh karena itu, dibutuhkan sistem akuntansi penjualan dan persediaan terkomputerisasi yang memadai yang dapat mempercepat dalam mencatat, merekam, menyimpan, mengolah dan menghasilkan data berupa laporan yang dibutuhkan sehingga efisiensi dan efektifitas kerja dapat tercapai. Serta dapat memberikan sistem informai akutansi penjualan dan persediaan yang cepat dan akurat.

Berdasarkan permasalahan yang terdapat di dalam Toko Dua Putri Pekanbaru, maka penulis melakukan penelitian mengenai sistem informasi akuntansi yang sedang berjalan dan mengajukan sebuah rancangan sistem yang baru untuk mengatasi masalah yang ada, yaitu dengan judul "Sistem Informasi Akutansi Penjualan dan Persediaan barang pada Toko Dua Putri Pekanbaru”.

\subsection{Identifikasi Masalah}

Berdasarkan uraian latar belakang masalah yang telah dikemukakan penulis, maka penulis merumuskan masalah dalam penelitian ini, yaitu :

1. Bagaimana sistem informasi akutansi penjualan dan persediaan barang pada Toko Dua Putri Pekanbaru?

2. Apa kelemahan sistem informasi akutansi penjualan dan persediaan barang pada Toko Dua Putri Pekanbaru?

3. Bagaimana solusi yang akan dilakukan dalam mengatasi kelemahan sistem informasi penjualan dan persediaan pada Toko Dua Putri Pekanbaru.

\subsection{Tujuan dan Manfaat Penulisan}

\section{Tujuan Penulisan}

Adapun tujuan dari penelitian ini adalah :

a. Untuk mengetahui bagaimana sistem Informasi akutansi penjualan dan persediaan barang pada Toko Dua Putri Pekanbaru.

b. Untuk mengetahui apa kelemahan sistem informasi akutansi penjualan dan persediaan barang pada Toko Dua Putri Pekanbaru.

c. Untuk mengetahui bagaimana solusi dalam mengatasi kelemahan sistem informasi akutansi penjualan dan persediaan pada Toko Dua Putri Pekanbaru. 


\subsection{Manfaat Penulisan}

Dari tujuan-tujuan yang telah penulis sebutkan diatas diharapkan dapat memperoleh manfaat-manfaat sebagai berikut :

a. Bagi Penulis

Dalam penelitian ini akan memberi tambahan wawasan bagi penulis tentang penerapan sistem akuntansi penjualan tunai sebagai wahana menerapkan ilmu dan teori dalam praktek nyata di lapangan.

b. Bagi Pemilik Toko

Penelitian ini diharapkan dapat bermanfaat menjadi bahan masukan dan pertimbangan untuk memperbaiki sistem yang diterapkan perusahaan, sehingga sistem penjualan dan persediaan pada perusahaan dapat berjalan baik.

c. Bagi Pihak Lain

Laporan ini diharapkan dapat menjadi bahan referensi, sumber informasi bagi peneliti lainnya yang berhubungan dengan sistem informasi akutansi penjualan dan persediaan dan dapat menambah wawasan.

\subsection{Pembatasan Masalah}

Dari latar belakang masalah yang telah dipaparkan penulis, maka batasan masalah pada penelitian ini adalah membahas pencatatan sistem informasi akuntansi penjualan dan persediaan barang pada Toko Dua Putri Pekanbaru.

\section{METODE PENELITIAN}

\subsection{Waktu dan lokasi penelitian}

Penelitian dilakukan pada Toko Dua Putri Pekanbaru yang beralamat di Jalan Kesadaran No. 26 Kelurahan Tangkerang Labuai, kecamatan Bukit Raya Kota Pekanbaru, Riau, jadwal pelaksanaan penelitian dari tanggal 01 Mei 2020 sampai dengan 01 Agustus 2020.

\subsection{Jenis dan Sumber Data}
a) Data Primer
Data yang diperoleh secara langsung dari pemilik Toko Dua Putri Pekanbaru, dan hasil pengamatan secara langsung yang sesuai dengan kebutuhan contohnya wawancara.
b) Data Sekunder
Data yang diperoleh secara tidak langsung, contohnya arsip Toko Dua Putri Pekanbaru yang berupa faktur laporan penjualan dan persediaan

\subsection{Teknik Pengumpulan Data}

Teknik pengumpulan data yang dilakukan penulis dalam memperoleh data-data yang diperlukan adalah sebagai berikut :

a. Penelitian Lapangan (Field Reseach) yaitu penelitian yang dilakukan dengan cara melakukan peninjauan langsung ke tempat obyek penelitian dan memperoleh data primer. Cara-cara pengumpulan data primer melalui wawancara. Penulis mengajukan pertanyaan yang telah dipersiapkan terlebih dahulu secara tertulis maupun secara lisan mengenai masalah-masalah yang akan diteliti kepada pemilik toko.

b. Studi Literatur (Library Research) yaitu informasi yang didapat dari buku-buku catatan dan sumber-sumber lain yang berhubungan dengan masalah yang diteliti.

\subsection{Teknik Analisis Data}

Analisis data yang bersangkutan yaitu deskriptif kualitatif yaitu metode penelitian yang banyak digunakan pada penelitian yang bertujuan untuk menjelaskan suatu kejadian yang dihubungkan dengan teori yang relevan yang berhubungan dengan masalah yang dibahas 
untuk kemudian diambil suatu kesimpulan. Metode ini dipergunakan untuk menganalisa data yang berupa keterangan-keterangan yang diperoleh langsung dari Toko Dua Putri Pekanbaru.

\section{LANDASAN TEORI DAN KERANGKA PEMIKIRAN 3.1 Pengertian Sistem}

Menurut Azhar Susanto (2013:22) "Sistem adalah kumpulan (group) dari subsistem/bagian/komponen apapun baik fisik ataupun nonfisik yang saling berhubungan satu sama lain dan bekerjasama secara harmonis untuk mencapai satu tujuan tertentu".

Menurut Sutarman (2009:5), "Sistem adalah kumpulan elemen yang saling berinteraksi dalam suatu kesatuan untuk menjalankan suatu proses pencapaian suatu tujuan utama".

\subsection{Informasi}

Menurut Azhar Susanto (2008:38), "Informasi adalah hasil pengolahan data yang memberikan arti dan manfaat". Sedangkan menurut Baridwan (2005:5), "Informasi adalah data yang diolah sehingga dapat dijadikan dasar dalam pengambilan keputusan yang tepat". Berdasarkan pengertian diatas menunjukkan bahwa informasi merupakan hasil pengolahan data yang berguna sebagai dasar untuk mengambil keputusan.

\subsection{Pengertian Akutansi}

Menurut Mursyidi (2010:17) akuntansi adalah proses pengidentifikasian data keuangan, memproses pengolahan dan penganalisisan data yang relevan untuk diubah menjadi informasi yang dapat digunakan untuk pembuatan keputusan.

Menurut Elvi Maria Manurung (2011:1) akuntansi proses mencatat semua kejadian yang bersifat keuangan (disebut transaksi) dan melaporkannya dalam bentuk yang lazim disebut laporan keuangan untuk dikomunikasikan kepada para pengguna.

\subsection{Pengertian Sistem Informasi Akuntansi}

Sistem Informasi Akuntansi menurut Azhar Susanto (2008:72) adalah sebagai berikut :"Sistem Informasi Akuntansi dapat didefinisikan sebagai kumpulan (integrasi) dari sub sistem/komponen baik fisik maupun non fisik yang saling berhubungan dan bekerja sama satu sama lain secara harmonis untuk mengolah data transaksi yang berkaitan dengan masalah keuangan menjadi informasi keuangan”.

\subsection{Pengertian Penjualan}

Menurut Leny Sulistiyowati (2010:270) penjualan merupakan pendapatan yang berasal dari penjualan produk perusahaan, disajikan setelah dikurangi potongan penjualan dan retur penjualan.

\subsection{Persediaan}

Menurut Stince dan Skousen (2009 : 571), "Persediaan adalah istilah yang diberikan untuk aktiva yang akan dijual dalam kegiatan normal atau akativa yang dimasukkan secara langsung atau tidak langsung ke dalam barang yang akan di produksi dan kemudian dijual.

MeltMenurut Stice dan Skousen (2009 : 667), "Ada beberapa macam metode penilaian persediaan yang umum digunakan, yaitu : identifikasi khusus, biaya rata-rata (Average), masuk pertama, keluar pertama (FIFO), masuk terakhir, keluar pertama (LIFO)”.

a. Identifikasi Khusus

Pada metode ini, biaya dapat dialokasikan ke barang yang terjual selama periode berjalan barang yang ada di tangan pada akhir periode berdasarkan biaya aktual dari unit tersebut. Metode ini diperlukan untuk mengidentifikasi biaya historis dari unit persediaan. Dengan identifikasi khusus, arus biaya yang dicatat disesuaikan dengan arus fisik barang.

b. Metode Biaya Rata-Rata (Average)

Metode ini membebankan biaya rata-rata yang sama ke setiap unit. Metode ini didasarkan pada asumsi bahwa barang yang terjual seharusnya dibebankan dengan biaya rata-rata, yaitu 
rata-rata tertimbang dari jumlah unit yang dibeli pada tiap harga. Metode rata-rata mengutamakan yang mudah terjangkau untuk dilayani, tidak peduli apakah barang tersebut masuk pertama atau masuk terakhir.

c. Metode Masuk Pertama, Keluar Pertama (FIFO)

Metode ini didasarkan pada asumsi bahwa unit yang terjual adalah unit yang terlebih dahulu masuk. FIFO dapat dianggap sebagai sebuah pendekatan yang logis dan realistis terhadap arus biaya ketika pengguna metode identifikasi khusus

\subsection{Sistem Informasi Akuntansi Persediaan}

Menurut Krismiaji prosedur yang diterapkan pada sistem informasi akuntansi persediaan :

1. Prosedur permintaan pembelian persediaan.

2. Prosedur pemesanan persediaan.

3. Prosedur retur dan potongan pembelian atau penjualan persediaan.

4. Prosedur pengiriman persediaan.

5. Prosedur penerimaan dan penyimpanan persediaan.

6. Prosedur pengeluaran persediaan.

7. Prosedur pencatatan akuntansi persediaan.

8. Prosedur pengendalian dan evaluasi persediaan.

Menurut Arens, Elder, dan Beasley $(2007,309)$ prosedur yang diterapkan adalah:
a. Prosedur pesanan pembelian persediaan
a. Prosedur penerimaan persediaan
b. Prosedur penyimpanan dan pengeluaran persediaan
c. Prosedur pengiriman barang
d. Prosedur pencatatan
e. Prosedur evaluasi

Tujuan dari sistem informsi persediaan adalah sebagai berikut:

a) Memberikan informasi mengenai persediaan mulai dari pengakuan sampai proses penerimaannya dengan prosedur yang baku.

b) Memberikan informasi mengenai alur persediaan yang ada sehingga pemerintah daerah dapat memperhitungkan tingkat pengendalian yang diperlukan.

c) Pengendalian persediaan sehingga persediaan dapat diperhitungkan secara ekonomis keberadaannya.

\subsection{Microsoft Acces 2007}

Menurut Adi (2007:213) Microsoft Access adalah sebuah program aplikasi basis data komputer relasional yang ditujukan untuk kalangan rumahan dan perusahaan kecil hingga menengah, dan juga menggunakan tampilan grafis yang intuitif sehingga memudahkan pengguna.

Berikut adalah simbol dari bagan alir (flowchart) menurut Krismiaji adalah sebagai berikut ini :

\begin{tabular}{|c|l|l|}
\hline SIMBOL & \multicolumn{1}{|c|}{ NAMA } & \multicolumn{1}{c|}{ FUNGSI } \\
\hline$\longleftarrow \downarrow \uparrow$ & Arus (Flow) & $\begin{array}{l}\text { Penghubung antara prosedur atau } \\
\text { proses }\end{array}$ \\
\hline
\end{tabular}




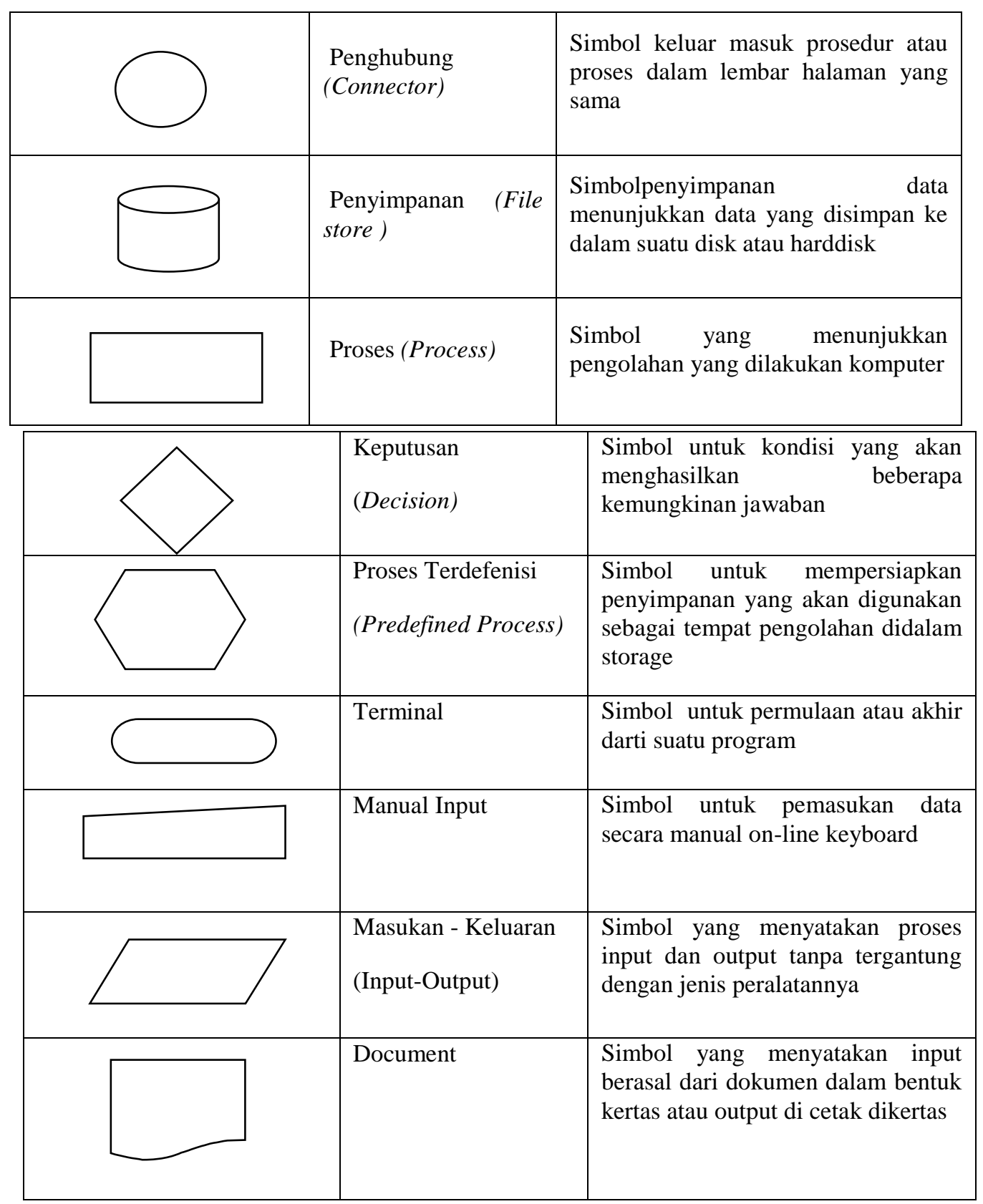

\section{Tabel. 2.1 Simbol Flowchart}

\section{HASIL DAN PEMBAHASAN}

\subsection{Analisis Sistem yang Sedang Berjalan}

Toko Dua Putri Pekanbaru dalam mengelolah data pencatatan penjualan dan persediaan barang masih menggunakan cara manual yaitu melakukan catatan tulis tangan di kertas biasa dan menggunakan alat kalkulator dalam penjumlahan barang. Sehingga membutuhkan tenaga dan dan waktu yang cukup lama dalam proses pencatatan penjualan dan persediaan barang.

Dalam pencatatan persediaan barang di dalam toko sering dijumpai masalah seperti hasil pencatatan persediaan tidak sesuai, kerusakan barang, pemasukan barang tidak sesuai dengan pemesanan, dan belum mempunyai sistem yang dapat memberikan informasi baik berupa data persediaan, data pemesanan maupun data penjualan. Ini dikarenakan kurangnya informasi dan 
penyimpanan pencatatan laporan stok barang tersebut sehingga toko kesulitan dalam mendapatkan informasi secara akurat.

Seharusnya toko mempunyai sistem informasi yang terintegrasi antara bagian tertentu dengan bagian yang bersangkutan supaya informasi yang didapat tidak salah. Untuk itu sangatlah diperlukan kerja sama antara bagian penjualan dengan bagian gudang. Supaya tidak kesulitan dalam pembuatan laporan penjualan dan pencatatan persediaan bisa dikelola dengan efektif dan efesien dan juga tidak memakan waktu yang lama.

\section{Kelebihan dan Kelemahan Sistem yang Berjalan}

Kelebihan dari sistem yang berjalan pada Toko Dua Putri Pekanbaru adalah:

a. Memenuhi Prosedur order penjualan, dalam prosedur ini bagian penjualan melaksanakan tugasnya dengan menerima order dari pembeli dan membuat faktur penjualan tunai.

b. Memenuhi Prosedur penerimaan kas, dalam prosedur ini fungsi kas menerima pembayaran harga barang dari pembeli dan memberikan tanda bukti pembayaran tansaksi dilakukan antara karyawan dengan kasir.

c. Prosedur penyerahan barang, dalam prosedur ini melaksanakan penyerahan produk yang telah dibeli oleh pembeli.

Kelemahan dari sistem yang berjalan pada Toko Dua Putri Pekanbaru adalah

1) Bagian penjualan dalam membuat nota penjualan tunai masih menggunakan sistem manual yaitu dengan menggunakan nota penjualan yang ditulis dikertas biasa.

2) Bagian penjualan menggunakan kalkulator dalam menjumlah maupun mengalikan harga barang yang mengkibatkan tidak akuratnya hasil yang diterima yang menyebabkan kerugian bagi Toko Dua Putri Pekanbaru.

3) Memerlukan waktu yang lama dalam membuat atau menjumlahkan nota penjualan.

Berikut adalah Flowchat sistem informasi penjualan yang sedang berjalan di Toko Dua Putri Pekanbaru. 


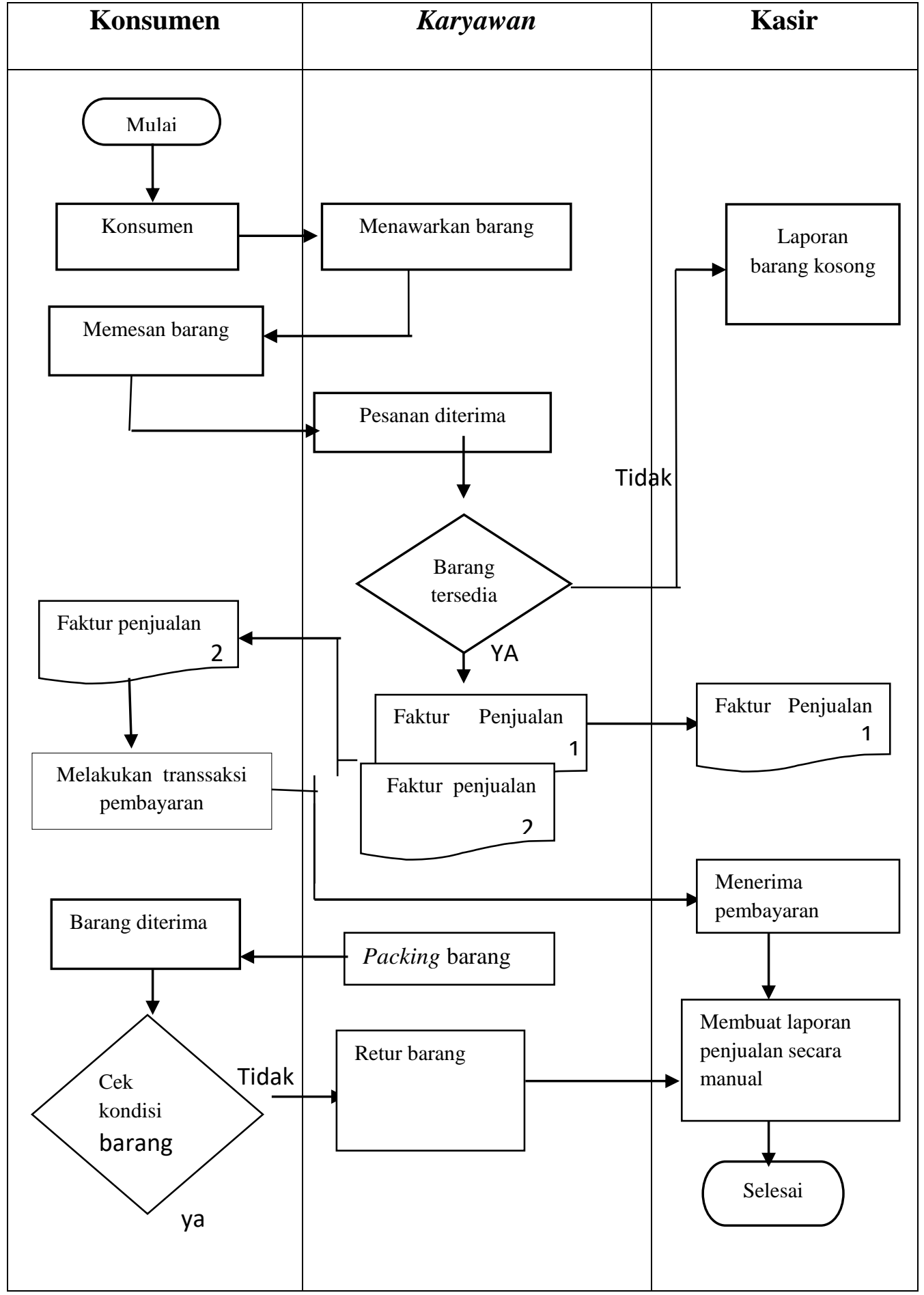

Gambar 4.1 Flowchart penjualan yang berjalan pada toko Dua Putri Pekanbaru

Berdasarkan gambar 4.1 diatas dijelaskan bahwa flowchart penjualan barang pada Toko Dua Putri Pekanbaru;

1. Konsumen datang ke Toko Dua Putri Pekanbaru

2. Karyawan menawarkan barang yang hendak dijual pada konsumen.

3. Konsumen memesan barang. 
4. Karyawan menerima pesanan dan mengecek barang. Jika barang tersedia maka karyawan membuat faktur dua rekapan.

5. Karyawan memberitahu kepada kasir jika barang tidak tersedia dan memberi rekapan 1 dan rekapan 2 diberi kepada konsumen.

6. Setelah konsumen menerima rekap faktur, maka konsumen melakukan transaksi pembayaran pada kasir dan membuat laporan penjualan secara manual.

7. Dan bagian karyawan packing barang dan memberi kepada konsumen

8. Konsumen menerima barang dan melakukan pengecekan barang jika barang yang diterima kondisinya tidak bagus maka melakuakn retur.

Berikut adalah Flowchat sistem informasi persediaan pada Toko Dua Putri Pekanbaru yang sedang berjalan: 


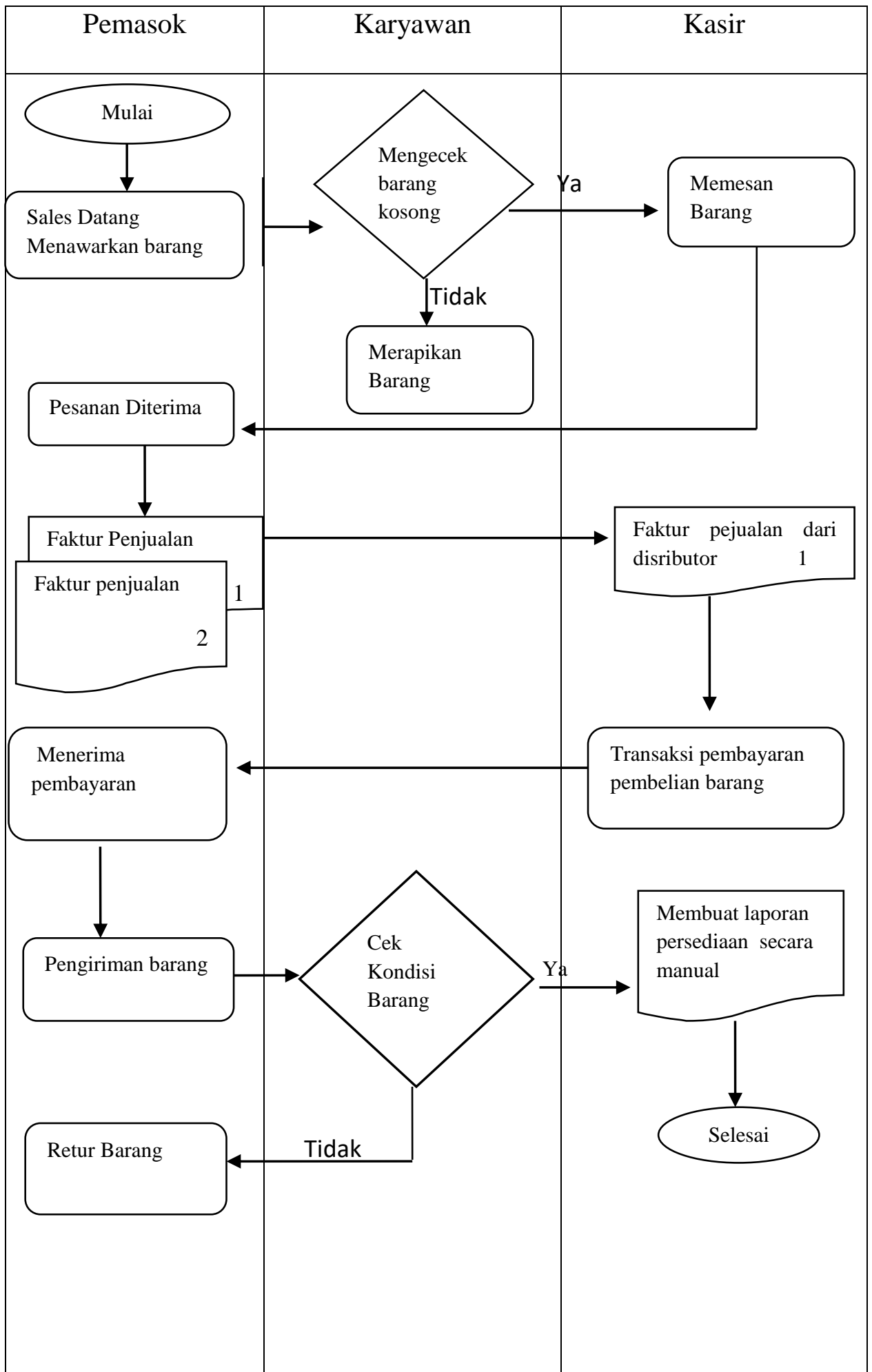

Gambar 4.2 Flowchat Persediaan barang masuk

Berdasarkan gambar 4.2 diatas dijelaskan bahwa flowchart Persediaan barang masuk pada Toko Dua Putri Pekanbaru;

1. Distributor datang ke Toko Dua Putri Pekanbaru membawa barang dan menawarkan produk yang hendak dijual.

2. Karyawan mengecek barang yang kosong pada toko jika barang kosong maka karyawan melapor ke bagian kasir dan kasir memesan barang pada pemasok. 
3. Pemasok menerima pesanan dan membuat faktur penjualan sebanyak 2 rekapan, dimana rekapan ke 1 diberi kepada kasir.

4. Kasir melakukan tansaksi pembayaran kepada pemasok secara tunai.

5. Pemasok mengirimkan barang dan karyawan melakukan pengecekan barang yang diterima dari pemasok. Jika barang diterima dengan kondisi baik maka barang masuk ke gudang. Tetapi jika barang yang diterima rusak maka kasir melakukan retur kembali.

6. Kasir akan membuat laporan persediaan barang secara manual dengan hasil barang yang masuk dalam kondisi baik.

\section{Hasil dan Pemecahan Masalah}

Pada sistem usulan dibuat untuk membantu memecahkan permasalahan sistem informasi akutansi penjualan dan persediaan pada Toko Dua Putri Pekanbaru, penulis mengusulkan untuk menggunakan aplikasi Microsoft Excel 2019 yang memiliki kemampuan dalam melakukan pencatatan semua transaksi penjualan dan pengelompokkan pencatatan transaksi penjualan sesuai pencatatan masing-masing.

Dengan menggunakan aplikasi Microsoft Excel 2019 memberikan solusi kemudahan dalam pembuatan data laporan hasil penjualan dan persediaan barang pada Toko Dua Putri Pekanbaru. Selain itu, menggunakan aplikasi dapat membuat laporan penjualan dan persediaan dengan cepat dan akurat. Sehingga hasil penjualan dan persediaan barang di dalam toko bisa lebih seimbang dan tidak akan mengalami kerugian lagi.

\subsection{Kelebihan dan Kelemahan Sistem yang Diusulkan}

Kelebihan dari sistem yang diusulkan pada Toko Dua Putri Pekanbaru adalah :

a. Sistem informasi akuntansi penjualan tunai yang diusulkan dapat memudahkan pekerjaan dan dapat menghasilkan informasi-informasi yang dibutuhkan oleh kasir secara cepat, tepat, efisien, dan ekonomis untuk membantu pengambilan dan pengelolaan keputusan dalam perkembangan usaha.

b. Pada sistem informasi akuntansi penjualan tunai yang diusulkan dapat memperoleh hasil penghitungan yang akurat sehingga tidak menyebabkan kerugian bagi pihak toko.

c. Pada sistem akuntansi penjualan tunai yang diusulkan dapat menghasilkan laporan penjualan tunai dan laporan keuangan dengan cepat dan akurat tanpa membuat laporan tersebut secara manualisasi.

d. Pada sistem akuntansi informasi penjualan tunai yang diusulkan dapat menghasilkan salinan data seperti salinan data pesanan penjualan (sales order), faktur (invoice) penjualan tunai, laporan penjualan dan laporan keuangan.

e. Aplikasi tersebut mampu menghitung penambahan dan pengurangan penjualan.

f. Dapat menampilkan data penjualan kapan dibutuhkan dan dapat menghasilkan informasi laporan bulanan serta laporan tahunannya.

g. Dapat menampilkan penjualan atau keuntungan dari setiap penjualan

h. Proses pembuatan laporan dengan kriteria tertentu dapat dilakukan dengan cepat dan akurat.

Kelemahan dari sistem yang diusulkan pada Toko Dua Putri Pekanbaru adalah :

1. Memerlukan ketaatan karyawan dalam mendistribusikan dokumen yang diperlukan agar memperoleh hasil yang maksimal.

2. Perangkat yang digunakan dalam penjualan tunai yang disarankan menggunakan aliran listrik, sehingga ketika terjadi pemadaman listrik proses penjualan tunai terhenti sejenak. 
Berikut ini sistem informasi akutansi penjualan yang dusulkan di dalam Toko Dua Putri

\section{Pekanbaru}

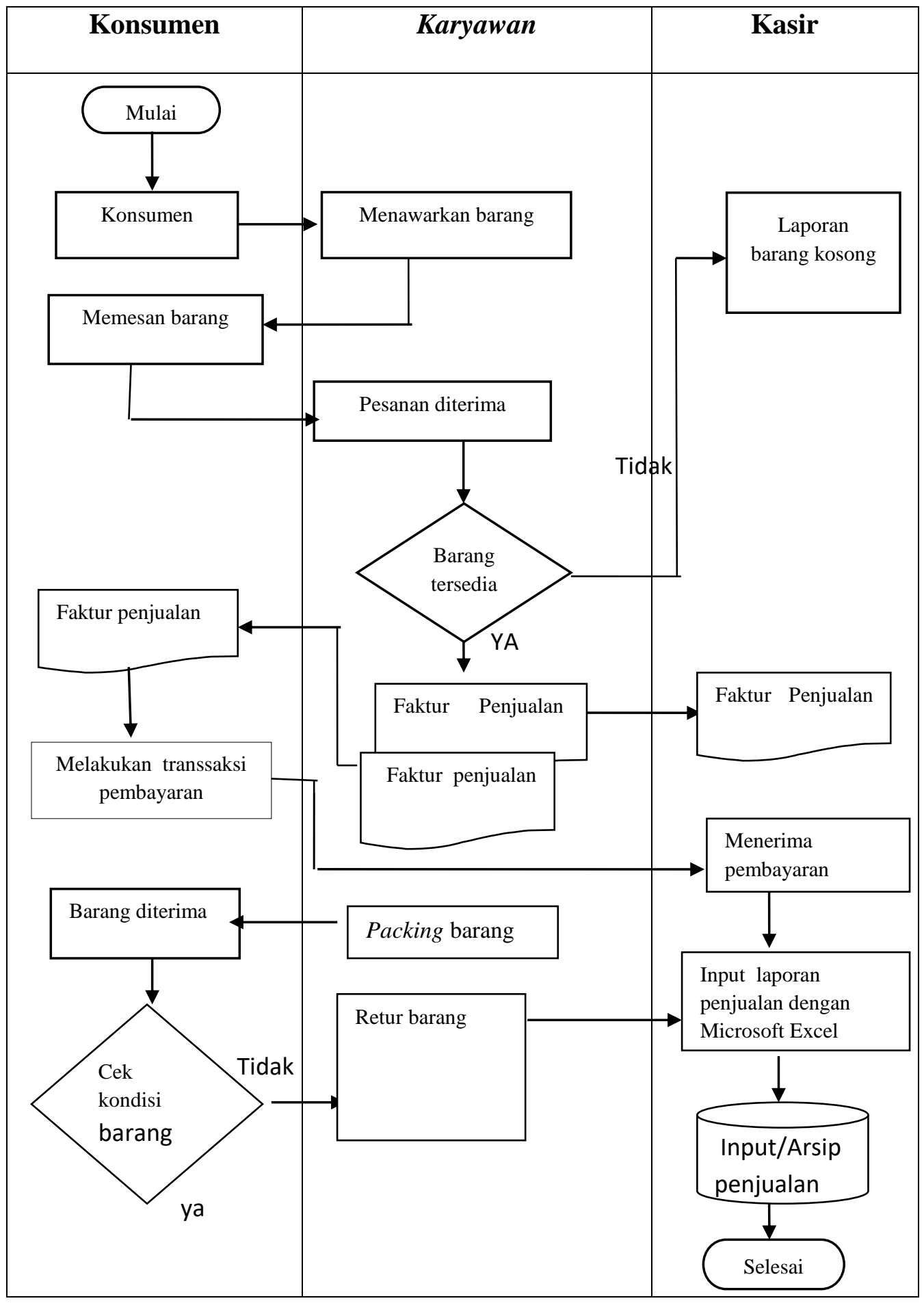

Gambar 4.3 Flowchat penjualan pada Toko Dua Putri Pekanbaru 
Berdasarkan gambar 4.3 diatas dijelaskan bahwa flowchart sistem penjualan baru yang diusulkan pada Toko Dua Putri Pekanbaru, yaitu sebagai berikut:

a. Konsumen datang ke Toko Dua Putri Pekanbaru untuk membeli sesuai kebutuhannya.

b. Karyawan menawarkan barang dan memperlihatkan ke konsumen.

c. Konsumen memilih barang sesuai keinginannya dan disiapkan oleh karyawan.

d. Karyawan memberi daftar beli yang tersedia untuk dibuat nota oleh bagian kasir.

e. Bagian kasir memberi informasi untuk mencatat penjualan di aplikasi Microsoft Excel 2019.

f. Bagian kasir memberi nota kepada konsumen untuk melakukan pembayaran.

g. Bagian karyawan packing barang dan menyerahkan barang kepada konsumen.

h. Konsumen menerima barang dan mencek kondisi barang. Jika kondisi baik maka barang diterima akan tetapi jika ada dalam keadaan rusak maka barang tersebut di retur kembali.

Berikut adalah Flowchat Sistem informasi persediaan pada Toko Dua Putri Pekanbaru Dengan Microsoft Excel 2019: 


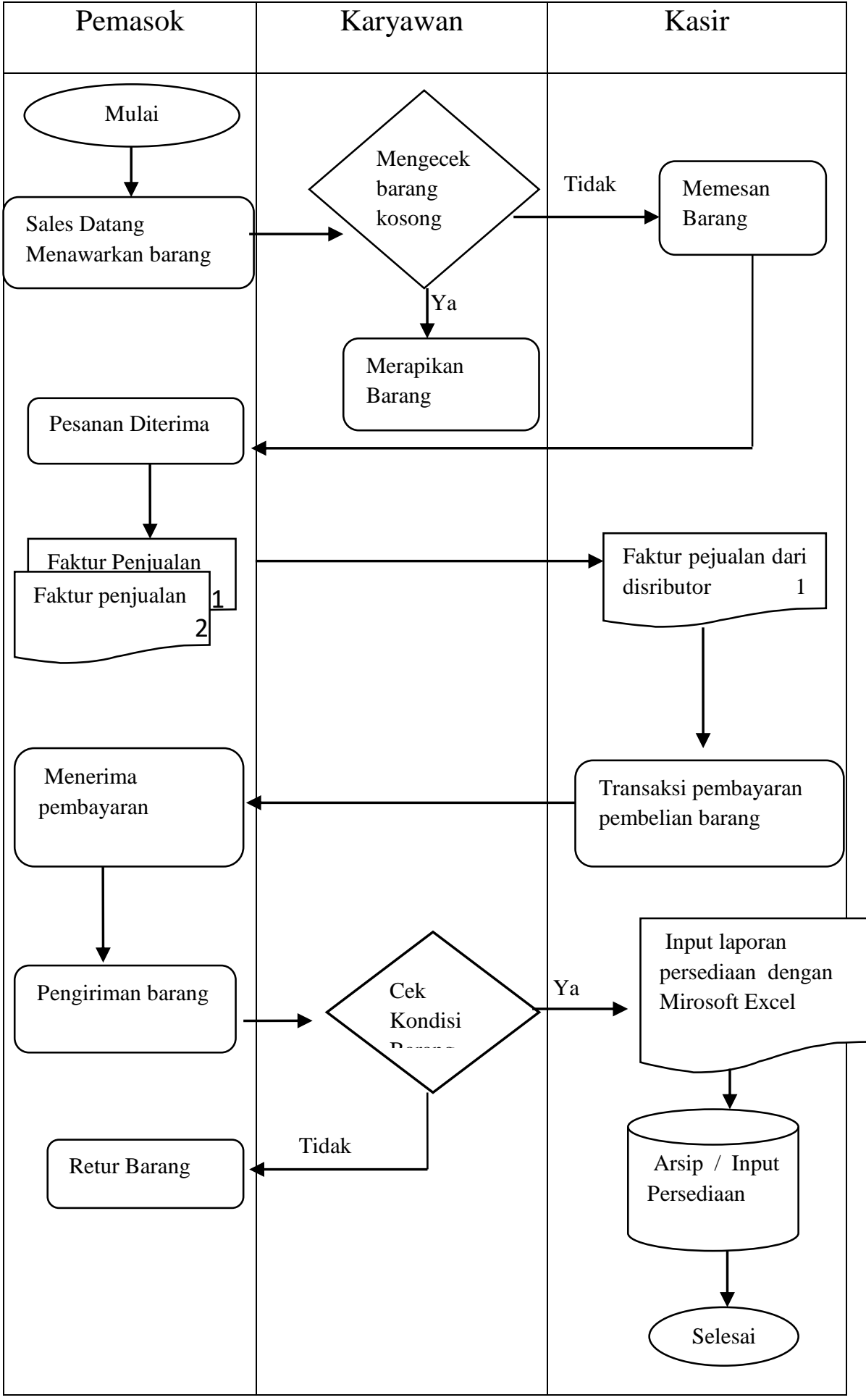

Gambar 4.4 Flowchat Persediaan

Berdasarkan gambar 4.4 diatas dijelaskan bahwa flowchart sistem penjualan baru yang diusulkan pada Toko Dua Putri Pekanbaru, yaitu sebagai berikut:

1. Distributor datang ke Toko Dua Putri Pekanbaru membawa barang dan menawarkan produk yang hendak dijual.

2. Karyawan mengecek barang yang kosong pada toko jika barang kosong maka karyawan melapor ke bagian kasir dan kasir memesan barang pada pemasok. 
3. Pemasok menerima pesanan dan membuat faktur penjualan sebanyak 2 rekapan, dimana rekapan ke 1 diberi kepada kasir.

4. Kasir melakukan tansaksi pembayaran kepada pemasok secara tunai.

5. Pemasok mengirimkan barang dan karyawan melakukan pengecekan barang yang diterima dari pemasok. Jika barang diterima dengan kondisi baik maka barang masuk ke gudang. Tetapi jika barang yang diterima rusak maka kasir melakukan retur kembali.

6. Kasir akan membuat laporan persediaan barang secara terkomputerisasi dengan menggunakan aplikasi Microsoft Excel 2019 dengan hasil barang yang masuk dalam kondisi baik.

\section{KESIMPULAN dan SARAN 6.1 Simpulan}

Berdasarkan penelitian dan pengamatan yang dilakukan penulis terhadap sistem informasi akuntansi penjualan dan persediaan yang berjalan selama ini pada Toko Dua Putri Pekanbaru, maka penulis memberi simpulan yaitu sistem akutansi penjualan dan persediaan pada Toko Dua Putri Pekanbaru masih melakukan pencatatan secara manual yang masih menggunakan buku besar secara tulis tanggan sehingga sering terjadi kesalahan dalam pencatatan dan dalam memberikan informasi yang kurang akurat dan lambat.

Tidak akuratnya hasil penjumlahan persediaan yang dilakukan pada saat pengecekan barang. Sehingga akan menyebabkan kerugian bagi Toko Dua Putri Pekanbaru. Untuk itu perlunya pengecekan barang setiap masuk dan keluar barang serta pemeriksaan catatan persediaan dengan hitungan yang sesuai. Karena cukup banyaknya produk barang yang masuk dan keluar sehingga perlu dilakukan pengendalian persediaan barang pada toko.

Berdasarkan sistem informasi akuntansi penjualan dan pencatatan persediaan yang sedang berjalan dalam toko, maka diusulkan sistem akuntansi yang terkomputerisasi contohnya dengan menggunakan sebuah aplikasi yaitu Microsoft Excel 2019. Dengan adanya aplikasi tersebut dapat memudahkan pekerjaan dan dapat menghasilkan informasi-informasi yang dibutuhkan oleh pemilik secara efektif dan efisien.

\subsection{Saran}

Berdasarkan simpulan diatas, saran yang dapat diberikan oleh penulis berkaitan dengan penelitianini yaitu

1. Melakukan stock opname persediaan barang 2 kali dalam sebulan agar tidak ada kehilangan barang atau mengecek barang yang sudah tidak layak dijual. Dan perlu meningkatkan pengawasan terhadap pemasukan persediaan dan barang terjual agar tidak terjadi kerusakan barang, ataupun kehilangan barang.

2. Melakukan penataan letak barang sesuai dengan jenis barang agar konsumen lebih mudah mendapatkan barang yang akan dibeli.

3. Toko Dua Putri Pekanbaru disarankan menggunakan aplikasi yang terkomputerisasi yaitu aplikasi microsoft Excel 2019 agar dapat menjalankan sistem informasi penjualan dan persediaan yang dapat mengefisiensikan waktu dalam pelaksanaan proses transaksi yang lebih akurat.

4. Perlunya dilakukan pelatihan terhadap karyawan atau kasir yang akan menggunakan komputer dalam applikasi Microsoft Excel.

5. Untuk penelitian kedepannya diharapkan untuk menggunakan aplikasi lain yang lebih akurat dan efisien. 


\section{DAFTAR PUSTAKA}

Agus Mulyanto. 2009. Sistem Informasi Konsep dan Aplikasi. Yogyakarta. PustakaPelajar

Azhar Susanto, (2013), Sistem Informasi Akuntansi, -Struktur-Pengendalian-ResikoPengembangan, Edisi Perdana, Lingga Jaya, Bandung

Gaol, L, Jimmy. 2008. Sistem Informasi Manajemen Pemahaman dan Aplikasi. Jakarta : Penerbit PT Grasindo

Jogiyanto. (2010). Metodologi Penelitian Bisnis. Edisi Pertama, BPFE. Yogyakarta

Leny Sulistiyowati. (2010). Panduan Praktis Memahami Analisis Laporan Keuangan. Elex Media Komputindo. Jakarta

Mulyadi. 2008. Sistem Akuntansi. Jakarta: Salemba Empat

Krismiaji, Aryani Y. Anni, (2011). Akuntansi Manajemen. Edisi Kedua. Cetakan Pertama. UPP STIM YKPN. Yogyakarta

Sutarman. 2009. Pengantar teknologi Informasi. Jakarta : Bumi Aksara

Stice, Stice, Skousen. 2010. Akuntansi Keuangan, Buku I Edisi 16. PT Raja Jakarta: Grafindo Persada

Widjajanto, Nugroho. 2008. Sistem Informasi Akuntansi. Jakarta. Erlangga, PT Gelora Aksara Pratama 